\title{
About SENC
}

The SENC (Sociedad Española de Nutrición Comunitaria - Spanish Community Nutrition Society) is the leading society of nutrition in Spain. It was created in 1989 with the ultimate goal of ameliorating food habits in Spain, and includes the following objectives:

1. To promote the assessment of nutritional status in the Spanish population by means of standardised methods.

2. To develop nutritional objectives and dietary guidelines for the population.

3. To foster the implementation of nutrition intervention programmes in the community; to contribute to the training of health professionals in nutrition fields.

4. To exchange experiences with other societies and associations, particularly in Latin America.

Since its foundation, the number of affiliates has been increasing and now includes more than 200 members, mainly physicians, pharmacists, dieticians, nurses and other health professionals; affiliates are involved in nutrition and public health responsibilities in universities, research centres, health settings, industries and national, regional and local health and agricultural administrations.

Its main activities are:

1. Organisation of a National Congress every two years and several workshops, conferences and symposia.

2. Editing of the Journal Revista Española de Nutrición Comunitaria (Spanish Journal of Community Nutrition).

3. Maintaining a web site.

4. Publication of documents, position papers and books.

5. Participation in studies, Research Protocols and Consensus Statements.

\section{National Congress}

The first SENC national conference was held in Barcelona in 1994 with the participation of around 300 individuals. It was organised as a Consensus Conference for the development of dietary guidelines in Spain in collaboration with World Health Organization (WHO) Europe, and emphasised the action plan to confront the deterioration of the Mediterranean diet in Spain. The publication appeared in 1995 (Serra-Majem L, Aranceta J, Mataix J. Documento de Consenso: Guias Alimentarias para la Población Española. Barcelona: SG editores, 1995).
The second conference was held in Granada in 1996 (including presentation of the dietary guidelines for the public) and the third in Las Palmas de Gran Canaria in 1998 (in which the First Ibero-American Conference of Nutrition and Public Health was constituted). In both congresses, the number of attendants surpassed 350 and the number of presentations increased exponentially, with more than 100 posters and oral communications in the Las Palmas de Gran Canaria conference. The latest conference was held in Bilbao in October 2000. A new Consensus on Nutritional Objectives and Dietary Guidelines was reached on this occasion, as well as the celebration of the Second Ibero-American Conference of Nutrition and Public Health, the creation of the IberoAmerican Network of Community Nutrition and the edition of several publications and documents. The number of attendants also surpassed 350 people, with an increased number of participants from Latin America.

The next conference will be in Madrid in October 2002. The preliminary programme is already available.

\section{Spanish Journal of Community Nutrition}

The Revista Española de Nutrición Comunitaria was first published in 1995. Since then, four issues have been published each year, and five supplements with a total of 94 articles. The official language is Spanish but articles in English are also accepted. It includes the following sections: Originals, Reviews, Epidemiology for Nutritionists, International News, Dietetics and Evidence-based Nutrition. The editors are Lluís Serra-Majem and Javier Aranceta. Most articles come from research groups in Spain (79\%), South America (11\%) and Europe (7\%). Queries should be directed to the following address: Dr Javier Aranceta, Director, Revista Española de Nutrición Comunitaria, Unidad de Nutrición Comunitaria, Subarea de Salud Pública, Luis Briñas 18, $3^{\mathrm{a}}-4^{\mathrm{a}}$ planta, E-48013 Bilbao, Spain.

\section{Website}

The web page of the SENC (www.nutricioncomunitaria.org) was initiated in 2001. It has four main sections: (1) information on the society; (2) a section for affiliates and professionals, including information on the journal, publications, activities, etc.; (3) a section for the public called Nutrition for all with the collaboration of the European Food Information Council (EUFIC); and (4) a section for the Ibero-American Nutrition Network. 
Future activities include the updating of Spanish Recommended Nutrient Intakes and continuing public education to help make better food choices and to improve the nutritional status of the population. This is achieved by intersectorial co-operation between scientists, professionals, government and the food industry.

The current Steering Committee (from October 2000) is composed of: Lluís Serra-Majem (President), Carmen Perez-Rodrigo (Vice-President), Rosa Ortega (Vice-President), Joan Fernandez-Ballart (General Secretary), Lourdes Ribas (Treasurer), Alberto Cepeda, Blanca
Gonzalvo, Ana $\mathrm{M}^{\mathrm{a}}$ López-Sobaler, Pepita Ortega, Joan Quiles, Gemma Salvador, Josep Antoni Tur (Members), Javier Aranceta (Director, Revista Española de Nutrición Comunitaria) and Jose Mataix (Honorary President).

Professor Lluís Serra-Majem (President)

Sociedad Española de Nutrición Comunitaria, Barcelona Science Park, Baldiri Reixac 4-6, E-08028 Barcelona, Spain

Tel.: +34-934-034-541; Fax: +34-934-034-543; Email: Senc@pcb.ub.es; Website: www.nutricioncomunitaria.org. 